\title{
Immunosuppressive Properties of Methotrexate: Apoptosis and Clonal Deletion of Activated Peripheral T Cells
}

\author{
Laurent Genestier, ${ }^{\star}$ Romain Paillot, ${ }^{*}$ Sylvie Fournel, ${ }^{\star}$ Carole Ferraro, ${ }^{*}$ Pierre Miossec, ${ }^{\ddagger}$ and Jean-Pierre Revillard ${ }^{\star}$ \\ *Laboratory of Immunology, Institut National de la Santé et de la Recherche Médicale U80 Claude Bernard University, and \\ ${ }^{\ddagger}$ Immunorheumatology Unit, Hôpital E. Herriot, 69437 Lyon, France
}

\begin{abstract}
The folate antagonist methotrexate (MTX) is extensively used in graft-versus-host disease, rheumatoid arthritis, and other chronic inflammatory disorders. In addition to its antiinflammatory activity associated with increased release of adenosine, MTX exerts antiproliferative properties by inhibition of dihydrofolate reductase and other folate-dependent enzymes. However, the mechanisms of immunosuppressive properties associated with low-dose MTX treatments are still elusive. We report here that MTX $(0.1-10 \mu \mathrm{M})$ induces apoptosis of in vitro activated $T$ cells from human peripheral blood. PBL exposed to MTX for $8 \mathrm{~h}$, then activated in drug-free medium, underwent apoptosis, which was completely abrogated by addition of folinic acid or thymidine. Apoptosis of activated $\mathrm{T}$ cells did not require interaction between CD95 (Fas, APO-1) and its ligand, and adenosine release accounted for only a small part of this MTX activity. Apoptosis required progression of activated $T$ cells to the $S$ phase of the cell cycle, as it was prevented by drugs or antibodies that interfere with IL-2 synthesis or signaling pathways. MTX achieved clonal deletion of activated $T$ cells in mixed lymphocyte reactions. Finally, in vitro activation of PBL taken from rheumatoid arthritis patients after MTX injection resulted in apoptosis. Altogether, the data demonstrate that MTX can selectively delete activated peripheral blood $\mathrm{T}$ cells by a CD95-independent pathway. This property could be used as a new pharmacological end point to optimize dosage and timing of MTX administration. It may account for the immunosuppressive effects of low-dose MTX treatments. (J. Clin. Invest. 1998. 102:322-328.) Key words: methotrexate $\cdot$ apoptosis $\bullet T$ lymphocytes $\bullet$ thymidylate synthase $\bullet$ rheumatoid arthritis
\end{abstract}

\section{Introduction}

Methotrexate (MTX) ${ }^{1}$ is a folate antagonist first developed for the treatment of malignancies (1) and, subsequently, used in nonneoplastic diseases as an antiinflammatory and/or immu-

L. Genestier and R. Paillot contributed equally to this work.

Address correspondence to Jean-Pierre Revillard, INSERM U80, Hôpital E. Herriot, Pav.P, 5 place d'Arsonval, 69437 Lyon Cedex 03, France. Phone: 33-4-72-11-01-56; FAX: 34-4-72-33-00-44; E-mail: revillard@lyon151.inserm.fr

Received for publication 29 December 1997 and accepted in revised form 12 May 1998.

J. Clin. Invest.

(C) The American Society for Clinical Investigation, Inc. 0021-9738/98/07/0322/07 \$2.00

Volume 102, Number 2, July 1998, 322-328

http://www.jci.org nosuppressive drug. MTX is currently the most commonly used treatment of rheumatoid arthritis $(2,3)$, and other chronic inflammatory disorders. MTX is also effective in the prophylaxis of acute graft-versus-host disease either alone or in association with cyclosporin A (CsA) and/or prednisone (4-6) or FK506 (7). MTX has also been used as an adjunct therapy for persistent mild cardiac allograft rejection (8). Most pharmacological studies have addressed the use of MTX in cancer chemotherapy, where doses could be escalated up to 30 $\mathrm{g} / \mathrm{m}^{2}$ by administration of the antidote leucovorin (folinic acid, citrovorum factor). In autoimmune diseases and allografts, however, MTX dosage is usually in a range of 7-15 $\mathrm{mg}$ per week, given orally or by intramuscular injections.

Biochemical pharmacology studies of MTX in tumor cell lines by J. Jolivet, B.A. Chabner, and co-workers have shown that MTX, like physiological folates, is converted to polyglutamate forms that are not readily transported across the cell membrane (9-11). Those polyglutamated derivatives not only inhibit dihydrofolate reductase (DHFR), the major MTX target, but also have markedly increased affinity for certain folate-dependent enzymes such as thymidylate synthase (TS), 5-amino imidazol-4-carboxamide ribonucleotide transformylase, and the triple complex of enzymes that interconvert various forms of reduced folate $(11,12)$. The enzyme responsible for MTX conversion, folylpolyglutamyl synthetase, catalyzes the addition of $\gamma$-linked glutamate groups to the end carboxyl group of the neighboring folyl glutamate, using ATP as its energy source. The activity of this enzyme, first demonstrated in erythrocytes and then in human liver, was shown to vary among tumor cell lines. Surprisingly, the polyglutamation of MTX in normal tissues, including the lymphoid system, has received little attention so far, and the sensitivity of resting or activated peripheral $\mathrm{T}$ cells to growth inhibition and, eventually, apoptosis in the presence of MTX concentrations, achieved during low-dose treatment, has not been investigated.

The present study addressed the in vitro activity of MTX on human PBL. We report here that MTX selectively induces apoptosis of activated but not resting lymphocytes, even after short term exposure to MTX and subsequent activation in drug-free medium, thus, providing the first evidence for an immunosuppressive activity of low-dose intermittent MTX administration. Selective susceptibility of activated T cells in the $\mathrm{S} / \mathrm{G} 2$ phase of the cell cycle may result in clonal deletion of $\mathrm{T}$ cells that are activated by antigen at the time of MTX administration.

1. Abbreviations used in this paper: ADA, adenosine deaminase; CsA, cyclosporin A; DHFR, dihydrofolate reductase; MLR, mixed lymphocyte reactions; MTX, methotrexate; RPM, rapamycin; TS, thymidylate synthase; TUNEL, Tdt-mediated dUTP-FITC nick end labeling. 


\section{Methods}

Reagents and monoclonal antibodies. MTX, folic acid, folinic acid, adenosine, thymidine, adenosine deaminase (ADA), $\alpha, \beta-$-methylene adenosine-5'-diphosphate (ACPD), PHA, PMA, ionomycin, concanavalin A, and Staphylococcus aureus enterotoxin B were obtained from Sigma Chemical Co. (St. Louis, MO). Rapamycin (RPM) and FK506 were a gift from A. Altman (La Jolla Institute for Allergy and Immunology, La Jolla, CA), and CsA was supplied by Sandoz Pharmaceutical Division (Novartis, Paris, France). The CD3 mAb OKT3 was from Cilag Laboratories (Levallois-Perret, France). The CD25 mAb ARIL-2 (IgG1) and anti-thymocyte globulins were a gift from 7 Alberici (Pasteur-Merieux, Lyon, France). The agonist (CH11, IgM) anti-human CD95 mAb was from Coulter-Immunotech (Marseille, France). The antagonist anti-human CD95 mAb ZB4 (IgG1) was from Kamiya Biomedical (Thousand Oaks, CA). The CD25, CD69, and CD95 mAbs (fluorescein isothiocyanate conjugates) were from Becton Dickinson (Mountain View, CA) and Immunotech (Marseille, France), respectively.

Cell preparation and culture. PBL were collected from healthy donors in the presence of sodium citrate. Blood was defibrinated, and then mononuclear cells were isolated by centrifugation on a layer of Histopaque $^{\circledR}$ (Sigma Chemical Co.). Those cell suspensions, referred to as PBL, contained $1.8 \pm 0.4 \%$ monocytes, as defined by CD14 expression. PBL were resuspended in Rosewell Park Memorial Institute culture medium (RPMI 1640; Sigma Chemical Co.), supplemented with $10 \%$ FCS or TCH medium (serum free; ICN, Orsay, France), $2 \mathrm{mM}$ L-glutamine, and antibiotics (penicillin $100 \mathrm{U} / \mathrm{ml}$, streptomycin $100 \mu \mathrm{g} / \mathrm{ml}$ ). Cultures were maintained at $37^{\circ} \mathrm{C}$ in a humid atmosphere containing $5 \% \mathrm{CO}_{2}$. During the last $8 \mathrm{~h}$ of incubation they were pulsed with (methyl- $\left.{ }^{3} \mathrm{H}\right)$ thymidine $\left(\left[{ }^{3} \mathrm{H}\right] \mathrm{TdR}\right.$; Amersham Int., Little Chalfont, UK) at $0.5 \mu \mathrm{Ci} /$ well. ${ }^{3} \mathrm{H}$-TdR uptake was measured using a Packard direct beta counter (Meriden, CT) after harvesting. For mixed lymphocyte reactions (MLR), the human B lymphoma cell lines RAJI and DAKIKI were used as stimulators (13). Stimulator cells were treated for $1 \mathrm{~h}$ at $37^{\circ} \mathrm{C}$ with $25 \mu \mathrm{g} / \mathrm{ml}$ of mitomycin C (29805; Serva Heidelberg, Germany), extensively washed, and then mixed with PBL at a ratio of $1 \mathrm{~B}$ cell for $10 \mathrm{PBL}$.

Measurement of nuclear apoptosis. After $3 \mathrm{~d}$ of culture, PHAactivated PBL were harvested. Dead cells were removed by centrifugation on a layer of Histopaque ${ }^{\circledR}$ (Sigma Chemical Co.). Viable cells $\left(10^{6} / \mathrm{ml}\right)$ were washed in HBSS, and then incubated in 96-well microplates (Costar, Cambridge, MA) with MTX. In other experiments, PBL were either incubated for 1-24 h in the presence of MTX, and then activated with PHA for 24 to $72 \mathrm{~h}$, or MTX and PHA were added together at the onset of the culture. Cell death was evaluated by fluorescence microscopy after staining with Hoechst 33342 (Sigma Chemical Co.) at $10 \mu \mathrm{g} / \mathrm{ml}$ after previously described methods (14). Apoptosis was also measured by flow cytometry after addition of biotinylated annexin V (Boehringer Mannheim, Indianapolis, IN; 15) and by TdT-mediated dUTP-FITC nick end labeling (TUNEL), as previously described (16), using reagents from Boehringer Mannheim. Samples were analyzed by flow cytrometry on a FACScan ${ }^{\circledR}$ (Becton Dickinson). Nuclear fragmentation and/or marked condensation of the chromatin with reduction of nuclear size were considered as typical features of apoptotic cells. Based on these measurements, results were expressed as percentage of apoptotic cells or percentage of specific apoptosis according to the following formula: specific apoptosis $=(\mathrm{T}-\mathrm{C}) /(100-\mathrm{C})$, where $\mathrm{T}$ stands for $\%$ of apoptotic-treated cells and $\mathrm{C}$ for $\%$ of apoptotic control cells.

The morphological features of the cells after MTX treatment were also observed by transmission electronic microscopy, as previously described (14). For DNA fragmentation assay, cells were incubated in RPMI medium for $12 \mathrm{~h}$ with MTX, and DNA preparations were obtained and processed for electrophoresis in $2 \%$ agarose gel after previously described methods (17).

Immunofluorescence assays. After $1 \mathrm{~d}$ of culture, cells were washed with isotonic $\mathrm{NaCl} / \mathrm{Pi}$ buffer containing $1 \% \mathrm{BSA}$ and $0.2 \%$
$\mathrm{NaN}_{3}$ (PBS/BSA/azide), and then incubated with $10 \mu \mathrm{l}$ of fluorescein isothiocyanate conjugated $\mathrm{CD} 25, \mathrm{CD} 69$, or CD95 $\mathrm{mAb}$ per $5 \times 10^{5}$ cells for $30 \mathrm{~min}$ at $4^{\circ} \mathrm{C}$. After two washes in PBS/BSA/azide, cell were fixed with $1 \%$ formaldehyde in PBS/BSA/azide. Lymphocytes were identified by cell size (small angle light diffraction) and this fraction was gated for analysis, thereby excluding dead cells but including small lymphocytes and blasts. To evaluate the mitochondrial transmembrane potential $\left(\Delta \psi_{\mathrm{m}}\right)$, cells $\left(5 \times 10^{5} / \mathrm{ml}\right)$ were incubated with 3,3'-dihexyloxacarbocyanine $\left(\operatorname{DiOC}_{6}(3)\right) 40 \mathrm{nM}$ in PBS (Molecular Probes, Inc., Eugene, OR) for $15 \mathrm{~min}$ at $37^{\circ} \mathrm{C}$, followed by flow cytometry analysis ( $\lambda$. Ex. Max., $488 \mathrm{nM} ; \lambda$. Em. Max., $525 \mathrm{~nm}$ ). The decrease in $\Delta \psi_{\mathrm{m}}$ is a characteristic of apoptotic cells (18).

CD95-ligand mRNA quantification was carried out following methods described in detail in another report (19).

Patients. Peripheral blood from one patient with a defect in the CD95 apoptotic signaling pathway was kindly made available by Alain Fischer (Hôpital des Enfants Malades, Paris, France). Details of the phenotypic alterations of this patient have been previously reported (20). Six patients with rheumatoid arthritis treated by weekly intramuscular injections of MTX $(7.5 \mathrm{mg}$ in one patient, $12.5-15 \mathrm{mg}$ in the five others) in the clinical immunology unit, Hôpital E. Herriot (patients of P. Miossec) gave their informed consent for blood sampling $(5 \mathrm{ml})$ before, and 6, 24, and $48 \mathrm{~h}$ after MTX injection. Cells were cultured with or without PHA.

\section{Results}

MTX induces apoptosis of mitogen-activated but not resting peripheral T cells. PBL were activated by PHA for $3 \mathrm{~d}$, and then dead cells were removed by centrifugation, and viable cells were incubated for $15 \mathrm{~h}$ with MTX $(1 \mu \mathrm{M})$. Apoptosis was demonstrated by internucleosomal fragmentation resulting in a typical "ladder" of 180-bp fragments and multiples thereof in agarose gel electrophoresis, whereas such fragments were not detected in nonactivated PBL (Fig. $1 A$ ). Apoptosis of PHAactivated cells, but not resting PBL was confirmed by typical condensation or fragmentation of cell nuclei, as revealed by Hoescht 33342 staining in fluorescence microscopy (Fig. $1 B$ ), electron microscopy (Fig. $1 C$ ), by the decrease of mitochondrial transmembrane potential $\left(\Delta \psi_{\mathrm{m}}\right)$ (Fig. $\left.1 D\right)$, and the presence of DNA breaks revealed by the TUNEL assay, (Fig. $1 D)$.

The kinetics of apoptosis showed a progressive increase up to $16 \mathrm{~h}(10 \mu \mathrm{M})$ or $28 \mathrm{~h}(0.1 \mu \mathrm{M})$ (data not shown). Similar observations were made with PBL activated by PMA plus ionomycin, concanavalin A, the CD3 mAb OKT3, polyclonal rabbit anti-thymocyte globulins and $S$. aureus enterotoxin $\mathrm{B}$, but not by PMA alone (data not shown). We concluded that MTX $(1 \mu \mathrm{M})$ induced apoptosis of activated T cells. A dose range of MTX concentrations was tested, demonstrating that apoptosis occurred at $0.1-10 \mu \mathrm{M}$, but not at $100 \mu \mathrm{M}$ (Fig. $2 A$ ). Counts of viable cells for $4 \mathrm{~d}$ after removal of PHA showed a progressive increase in controls (without MTX), a borderline decrease in the presence of MTX at 0.01 and $100 \mu \mathrm{M}$, and a considerable loss of viable cells with MTX at either 1 or $10 \mu \mathrm{M}$ (Fig. 2 B). When compared with measurements of apoptosis, these data indicate that MTX at low $(0.01 \mu \mathrm{M})$ and high $(100 \mu \mathrm{M})$ concentrations inhibits cell proliferation without inducing apoptosis, whereas at intermediate concentrations (from 0.1 to 10 $\mu \mathrm{M})$, the decrease of viable cells is mostly accounted for by apoptosis. Addition of MTX at the onset of PHA activation resulted in a marked progressive decrease of viable cell counts in the presence of MTX (from 0.1 to $10 \mu \mathrm{M}$ ), whereas at low $(0.01 \mu \mathrm{M})$ and high $(100 \mu \mathrm{M})$ concentrations, MTX inhibited 



Figure 1. MTX induces apoptosis of activated but not resting T cells. PBL were incubated $3 \mathrm{~d}$ with medium or PHA $(5 \mu \mathrm{g} / \mathrm{ml})$. Dead cells were removed and viable cells were treated for $15 \mathrm{~h}$ with MTX $\left(10^{-6} \mathrm{M}\right) .(A)$ DNA fragmentation was evaluated by electrophoresis on $2 \%$ agarose gel (Medium and PHA, without (-) or with (+) MTX). ( $B$ and $C$ ) Morphology of activated PBL after Hoescht 33342 staining and by electron microscopy, respectively (without MTX (left) or with MTX (right)). (D) Alteration of the mitochondrial transmembrane potential $\left(\Delta \psi_{\mathrm{m}}\right)$ measured by staining with DiOC6 $_{[3]}$ and DNA strand breaks detection by the TUNEL assay as described in Methods. Numbers in each histogram refer to the percentage of cells below $\left(\right.$ DiOC6 $_{[3]}$ ) or above (TUNEL) the threshold of normal controls.

cell proliferation but induced only a moderate and/or delayed loss of viable cells (data not shown).

$P B L$ incubated with MTX undergo apoptosis upon subsequent activation in drug-free medium. Preincubation of PBL with MTX (from 0.1 to $50 \mu \mathrm{M}$ ) resulted in apoptosis on subsequent PHA activation for $24 \mathrm{~h}$ (Fig. $3 \mathrm{~A}$ ), and maximal apoptosis was attained after $8 \mathrm{~h}$ incubation with MTX (data not shown). To determine the half-life of MTX apoptosis-inducing activity, PBL were incubated with MTX $(1 \mu \mathrm{M})$ and, subsequently, cultured in drug-free medium for various time intervals before activation by PHA. Results indicate a progressive linear decrease of the percentage of apoptotic cells with an average half-life of $3 \mathrm{~d}$ (Fig. $3 \mathrm{~B}$ ). Counts of viable cells after PHA activation in drug-free medium demonstrated that MTX inhibits PHA-induced cell proliferation at 0.01 and $100 \mu \mathrm{M}$,
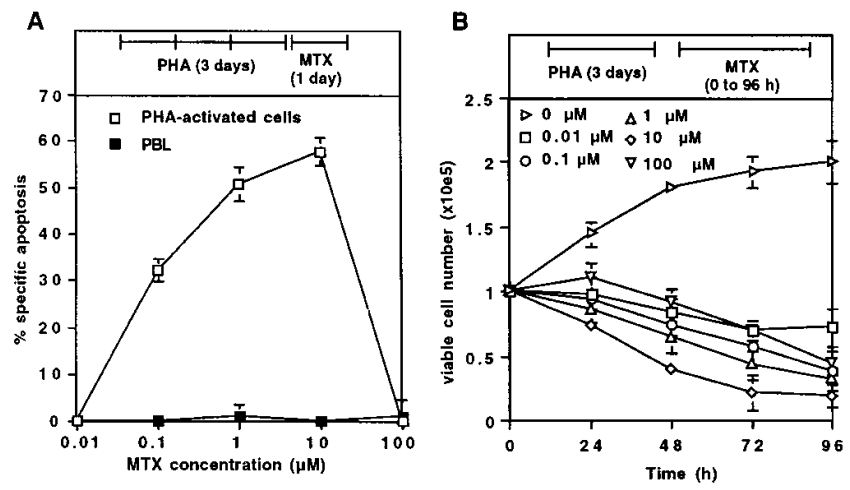

Figure 2. Characteristics of MTX-induced apoptosis. (A) Dose response: resting T cells $(\boldsymbol{\square})$ or cells activated by PHA $(5 \mu \mathrm{g} / \mathrm{ml})$ during $3 \mathrm{~d}(\square)$ were treated with a dose range of MTX. Apoptotic cells were evaluated after $24 \mathrm{~h}$. Values are the mean \pm SEM of three independent experiments. $(B)$ Effect of MTX on viable cell recovery. PBL were stimulated with PHA $(5 \mu \mathrm{g} / \mathrm{ml})$ without or with MTX $\left(10^{-8} \mathrm{M}\right.$ to $10^{-4} \mathrm{M}$ ) added at day 3 . Viable cell number was determined by trypan blue exclusion at the indicated times. Values are the mean \pm SEM of three independent experiments.

and induced a transient decrease of viable cell numbers at intermediate $(0.1-10 \mu \mathrm{M})$ concentrations (data not shown).

MTX-induced apoptosis of activated $T$ cells results from DHFR and TS inhibition. Knowing that MTX and its polyglutamated derivatives can interfere with several folate-dependent enzymes, we determined whether blockade of the two major targets of MTX activity, DHFR and TS, could account for MTX-induced apoptosis of activated T cells. To this end, 3-d PHA-activated cells were incubated with MTX $(1 \mu \mathrm{M})$ together with folic acid, folinic acid, or thymidine. Folinic acid showed dose-dependent inhibition of MTX activity, with $\sim 80 \%$ decrease at $1 \mu \mathrm{M}$ (Fig. $4 A$ ). Folic acid was $\sim 10-50$ times less effective on a molar basis, and complete inhibition required $100 \mu \mathrm{M}$. Increasing the extracellular concentration of
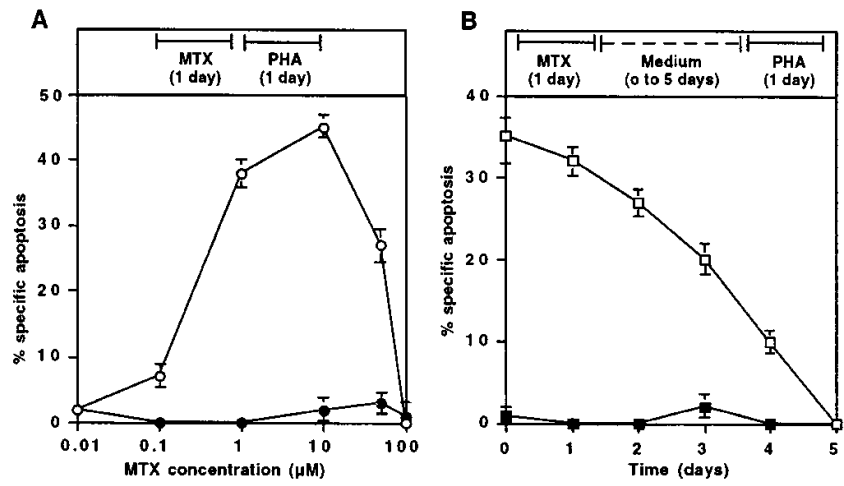

Figure 3. Apoptosis induced by MTX pretreatment: dose response $(A)$ and half-life of intracellular MTX $(B)$. PBL were incubated with a dose range of MTX $(A)$ or MTX $\left(10^{-6} \mathrm{M}\right)$ for $24 \mathrm{~h}(B)$. After removing the drug by two washes in HBSS, cells were immediately activated by PHA $(5 \mu \mathrm{g} / \mathrm{ml})(A)$ or maintained between 1 and $5 \mathrm{~d}$ in medium before PHA activation $(B)$. Percent apoptotic cells were evaluated at $24 \mathrm{~h}$ in control cell suspensions incubated in medium alone (closed symbols) or in cells cultured with PHA $(5 \mu \mathrm{g} / \mathrm{ml})$ (open symbols). Results are expressed as percent-specific MTX apoptosis. Values are the mean \pm SEM of four individual experiments. 

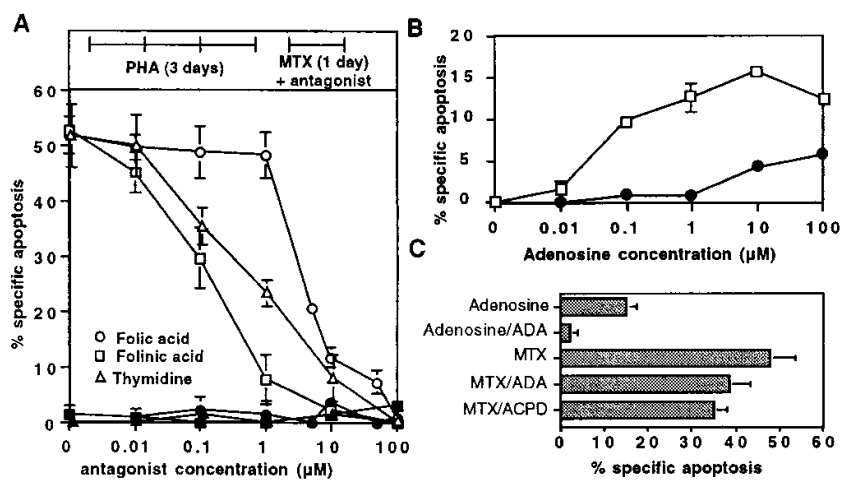

Figure 4. Effect of folic acid, folinic acid, or thymidine $(A)$; adenosine deaminase and ACPD on apoptosis induced by adenosine or MTX $(C)$. Resting T cells (closed symbols) or cells activated by PHA $(5 \mu \mathrm{g} / \mathrm{ml})$ in serum-free medium for $3 \mathrm{~d}$ (open symbols) were treated with MTX $\left(10^{-6} \mathrm{M}\right)$ plus a dose range of folic acid, folinic acid, or thymidine $(A)$ or with adenosine in serum-free medium. Identical values were observed in the presence of ACPD $(10 \mu \mathrm{M})(B)$. 3-d PHA-activated cells were incubated with ADA (2 U), or ACPD $(10 \mu \mathrm{M})$, and treated $24 \mathrm{~h}$ with MTX $\left(10^{-6} \mathrm{M}\right)$ or adenosine $\left(10^{-6} \mathrm{M}\right)(C)$. Apoptotic cells were evaluated after $24 \mathrm{~h}$, and results are expressed as percent-specific apoptosis as described in Methods. Values are the mean \pm SEM of three independent experiments.

thymidine to $10 \mu \mathrm{M}$ was sufficient to prevent $90 \%$ of MTXinduced apoptosis (Fig. $4 \mathrm{~A}$ ).

Adenosine plays a limited role in MTX-induced apoptosis. Knowing that adenosine represents the major mediator of the antiinflammatory activities of MTX (21), we investigated its contribution to MTX-induced apoptosis. Addition of adenosine $(0.1-1 \mu \mathrm{M})$ in serum-free medium with or without ACPD resulted in apoptosis of $\sim 15 \%$ of PHA-activated cells (Fig. $4 \mathrm{~B})$. At higher concentrations $(10-100 \mu \mathrm{M})$, adenosine induced some apoptosis of unactivated lymphocytes, but the percentage of apoptotic PHA-activated cells did not increase. The apoptotic activity of adenosine $(1 \mu \mathrm{M})$ was completely abrogated by adenosine deaminase, whereas that of MTX was only marginally decreased (Fig. $4 \mathrm{C}$ ). It was concluded that sensitivity to adenosine-mediated apoptosis was restricted to a subset of PHA-activated cells, accounting for $\sim 15-20 \%$ of cells susceptible to MTX.

$M T X$-induced apoptosis requires progression to the $S$ phase of the cell cycle. The apoptotic signal triggered by MTX is likely to be initiated at the time of DNA synthesis, during the S phase of the cell cycle. Supporting this hypothesis, the percentage of blasts and the cell surface expression of CD69, CD25 ( $\alpha$ chain of the IL-2 receptor), and CD95 (Fas, APO-1), that are typical markers of activated T cells in the G1 phase of the cell cycle were not decreased by MTX (Fig. $5 A$ ). Furthermore, inhibition of IL-2 synthesis by CsA or FK506, interference with IL-2 receptor signaling by rapamycin, and competition with IL-2 binding to its receptor by a CD25 mAb, all markedly decreased $\left[{ }^{3} \mathrm{H}\right] \mathrm{TdR}$ incorporation and reduced MTX-induced apoptosis in parallel (Fig. 5 B). None of the inhibitors used to interfere with the IL-2 pathway increased the basal level of apoptosis in the absence of MTX.

MTX-induced apoptosis does not involve CD95L/CD95 interaction. Activated $\mathrm{T}$ and $\mathrm{B}$ lymphocytes express the death- signaling receptor CD95 (Fas, APO-1), which mediates apoptosis upon oligomerization. Because MTX was reported to stimulate CD95 ligand (CD95L) mRNA expression in human leukemia T cell lines (22), we studied the possible contribution of CD95L/CD95 interaction in the apoptotic effect of MTX. Expression of CD95L mRNA by 3-d PHA-activated cells could be readily induced by the association of a phorbol ester with a calcium ionophore, whereas MTX $(10$ and $200 \mu \mathrm{M})$ triggered only borderline CD95L gene transcription (Fig. $6 \mathrm{~A}$ ). Apoptosis induced by MTX was not altered by addition of the CD95 antagonist antibody ZB4, which completely inhibits apoptosis induced by CD95L or by the CD95 agonist antibody CH11 (Fig. 6 B). PBL rapidly express CD95 upon activation, but their sensitivity to CD95-dependent apoptosis progressively develops from day 3 to day 6 of mitogenic activation, and requires IL-2 (23). After $24 \mathrm{~h}$ of mitogenic activation, PBL were fully susceptible to MTX-induced apoptosis (Figs. $3 \mathrm{~B}$ and $6 \mathrm{C}$ ), yet resistant to the CD95 agonist antibody $\mathrm{CH} 11$. Finally, PBL from a patient with normal CD95 expression but defective CD95 signaling pathway, as shown by their resistance to $\mathrm{CH} 11$-induced apoptosis, were fully susceptible to MTX (Fig. 6 D). It was concluded that MTX-induced apoptosis of mitogen-activated cells occurred through a CD95-independent pathway.

MTX induces clonal deletion of alloreactive T cells. Alloreactive $\mathrm{T}$ cells undergo activation and clonal expansion when cocultured with cells that express different MHC class II molecules, a reaction termed MLR (mixed lymphocyte reaction) (24). Subsequent culture with the same stimulator cells results in accelerated proliferation, as shown by a peak of $\left[{ }^{3} \mathrm{H}\right] \mathrm{TdR}$ incorporation and CD25 expression at 2-3 d, whereas the response to third party stimulator cells follows primary kinetics with maximal cell proliferation occurring after 5-6 d (13). Such differences indicate that the two types of stimulator cells are
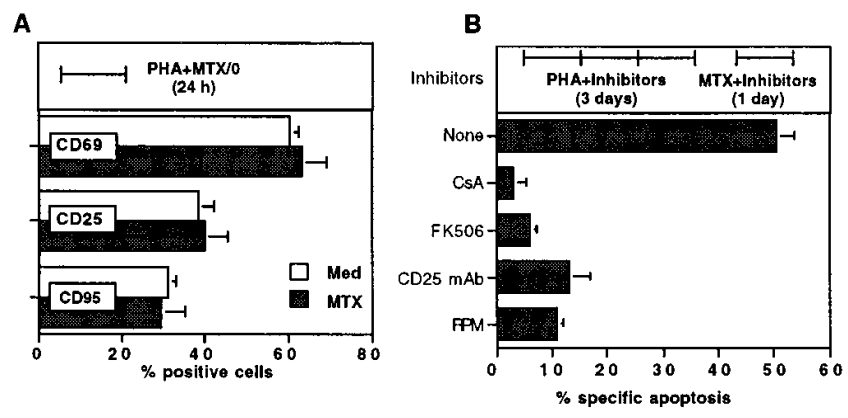

Figure 5. MTX-induced apoptosis and progression of activated PBL in the $\mathrm{S}$ phase of the cell cycle. PBL were activated by PHA $(5 \mu \mathrm{g} / \mathrm{ml})$ with or without MTX. $(A)$ Percentage of cells expressing G1 phase markers (CD69, CD25, CD95) among PHA-activated PBL after $24 \mathrm{~h}$ in the presence (gray bands) or absence (white bands) of MTX $\left(10^{-6} \mathrm{M}\right) .(B)$ Effect of inhibition of the $\mathrm{G}_{1}$ to $\mathrm{S}$ phase transition on MTX-induced apoptosis. PBL were activated by PHA $(5 \mu \mathrm{g} / \mathrm{ml})$ with or without CsA (250 ng/ml), FK506 (10 nM), CD25 mAb $(10 \mu \mathrm{g} / \mathrm{ml})$, and RPM $(60 \mathrm{nM})$. Results are expressed as the specific MTX apoptosis, as described in Methods. Values are the mean \pm SEM of four independent experiments. $\left[{ }^{3} \mathrm{H}\right] \mathrm{TdR}$ incorporation was determined during the last $8 \mathrm{~h}$ of culture with PHA: mean dpm (stimulation index in brackets). Nonactivated PBL: 300, PHA alone: 5,250 (17.5), PHA + CsA: 1,280 (4.2), PHA + FK506: 1,420 (4.7), PHA + CD25 mAb: 2,050 (6.8), PHA + RPM: 1,300 (4.3). 
A

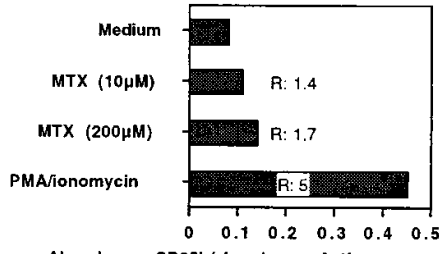

Absorbance CD95L/absorbance Actin

B

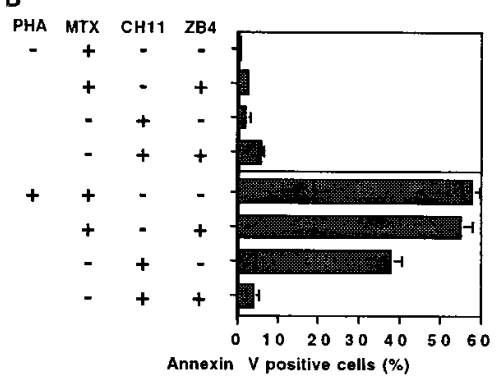

Annexin $V$ positive cells $(\%)$

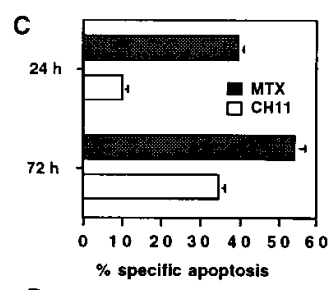

D

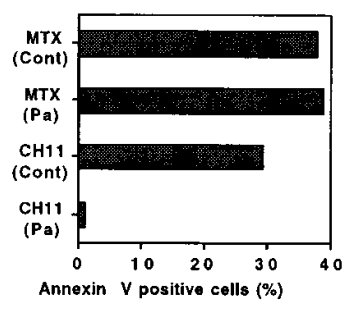

Figure 6. MTX-induced apoptosis does not involve CD95/CD95L interaction. PBL were cultivated for $3 \mathrm{~d}$ in the presence of PHA $(5 \mu \mathrm{g} / \mathrm{ml})$. Dead cells were eliminated by centrifugation on Ficoll, and viable cells were incubated with MTX $(10$ or $200 \mu \mathrm{M})$ or with PMA $(10 \mathrm{ng} / \mathrm{ml})$ plus ionomycin $(0.5 \mu \mathrm{g} / \mathrm{ml})$ for $12 \mathrm{~h}$. mRNA of each sample was amplified by reverse transcriptase-PCR as described in Methods, and separated on $2 \%$ agarose gel. Results are expressed as the ratio: absorbance of CD95L/absorbance of actin. $R$ corresponds to the ratio: absorbance assay/absorbance of medium. $(B)$ Effect of the antagonist Fas mAb ZB4 on MTX-induced apoptosis. 3-d PHAactivated cells were incubated $1 \mathrm{~h}$ with $\mathrm{ZB} 4$, and then treated with medium, MTX $\left(10^{-5} \mathrm{M}\right)$, or the agonist CD95 mAb CH11 $(1 \mu \mathrm{g} / \mathrm{ml})$ for $24 \mathrm{~h}$, and percentage of apoptotic cells was determined by annexin $\mathrm{V}$ binding. (C) Sensitivity to apoptosis induced by MTX and CD95 $\mathrm{mAb}$ CH11 according to culture duration. 1-d or 3-d PHA-activated cells were treated by MTX $\left(10^{-6} \mathrm{M}\right)$ or CD $95 \mathrm{mAb}$ CH11 $(1 \mu \mathrm{g} / \mathrm{ml})$ for $24 \mathrm{~h}$. The percentage of apoptotic cells was determined by flow cytometry after staining with annexin $\mathrm{V}$. Results are expressed as mean \pm SEM of four independent experiments. $(D)$ MTX-induced apoptosis in lymphocytes from a patient with a CD95-signaling defect. 3-d PHA-activated cells were treated with MTX $\left(10^{-6} \mathrm{M}\right)$ or CH11 $(1 \mu \mathrm{g} / \mathrm{ml})$. After $12 \mathrm{~h}$ of incubation, the percentage of apoptotic cells was determined by flow cytometry after staining with annexin $\mathrm{V}$.

recognized by distinct $\mathrm{T}$ cell clones, although cross-reactivity and/or HLA allele sharing between stimulator cells may often result in intermediate kinetics. To investigate whether a brief exposure to MTX could selectively delete activated $\mathrm{T}$ cells without impairing the functional capacities of other $\mathrm{T}$ cells in the same culture, we added MTX $(1 \mu \mathrm{M})$ during the last $16 \mathrm{~h}$ of a primary MLR. Cells were then incubated in fresh medium for $4 \mathrm{~d}$ to allow the decrease of intracellular MTX in accord with the kinetics shown in Fig. $3 C$, and the viable cells were then cocultured with either the same or a different allogeneic $\mathrm{B}$ cell line. In these conditions, the secondary response to identical stimulator cells was nearly completely abrogated, whereas the response to a third party cell line was not affected (Fig. 7), indicating that the effect of MTX was clonally restricted to the $T$ cells that were activated at the time of exposure to the drug.

Lymphocytes from MTX-treated patients undergo apoptosis upon in vitro activation. We verified in six rheumatoid arthritis patients, that a single injection of MTX during low-dose treatment was sufficient to prime lymphocytes to apoptosis

upon subsequent mitogenic activation ex vivo (Fig. 8). In vitro apoptosis, determined after $24 \mathrm{~h}$ of activation by PHA, was completely inhibited in the presence of folinic acid $(10 \mu \mathrm{M})$ and folic acid $(100 \mu \mathrm{M})$ (data not shown), indicating that it could be attributed to MTX or its polyglutamated derivatives.

\section{Discussion}

MTX was shown to exert a wide range of antiinflammatory activities $(21,25-27)$ that are primarily mediated by the release of adenosine from different cell types that express ecto- 5 nucleotidase (28). Such antiinflammatory properties do not exclude a genuine immunosuppressive activity, in as much as ADA deficiency is associated with a severe combined immunodeficiency disease (29). The present study demonstrates that MTX induces apoptosis of PBL activated by mitogens or superantigens, and may induce clonal deletion of alloreactive $\mathrm{T}$ cells at concentrations that are achieved during low-dose clinical treatments (30-32). Remarkably, nonactivated T cells were resistant to apoptosis at up to $1 \mathrm{mM}$ MTX, demonstrating a selectivity toward activated PBL. Furthermore, resting PBL incubated with MTX, and subsequently activated in drug-free medium, underwent apoptosis, suggesting that unactivated $\mathrm{T}$ cells may convert MTX to polyglutamate forms that are retained intracellularly. The ability to undergo apoptosis may reflect the capacity of PBL to convert MTX to MTX glu4 and MTX glu5, which were reported to be retained for up to $24 \mathrm{~h}$ in breast cancer cells $(10,11)$. In the present model, maximal apoptosis was achieved after $8 \mathrm{~h}$ of exposure to MTX and the half-life of the biological activity of polyglutamated MTX was around $3 \mathrm{~d}$. Such information may be relevant for optimizing dosage and time interval of MTX administration during lowdose treatments. Indeed PBL from MTX-treated rheumatoid arthritis patients underwent apoptosis upon ex vivo activation, although the percentage of apoptotic cells remained lower

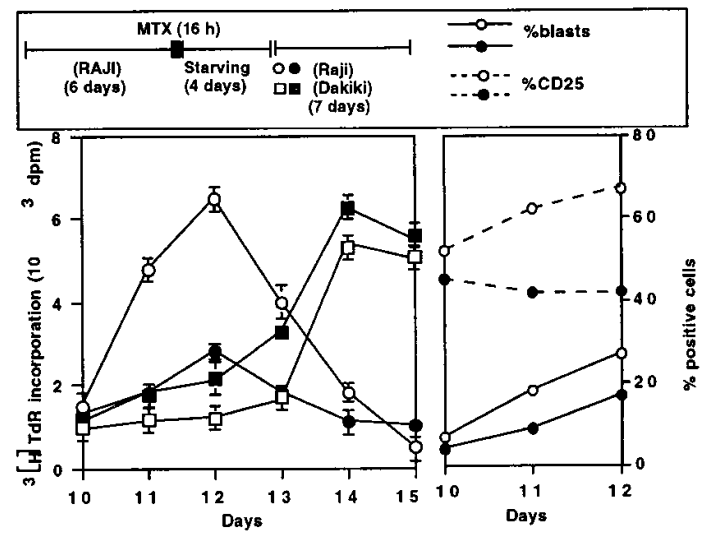

Figure 7. MTX-induced antigen-specific hyporesponsiveness in MLR. Lymphocytes from healthy adult donors were stimulated with RAJI cells with or without MTX $\left(10^{-6} \mathrm{M}\right)$ added during $16 \mathrm{~h}$ at day 6 (closed or open symbols, respectively). Lymphocytes were washed and cultured in fresh medium from day 6 to 10 , and then restimulated with RAJI or DAKIKI cells. $\left[{ }^{3} \mathrm{H}\right] \mathrm{TdR}$ incorporation in dpm (mean \pm $\mathrm{SD})$ and CD25 expression and blasts transformation (FACS ${ }^{\circledast}$ analysis) were measured sequentially during $6 \mathrm{~d}$ after addition of mitomycin-treated stimulator B cell lines. Results of one representative from three distinct experiments showing similar effects. 


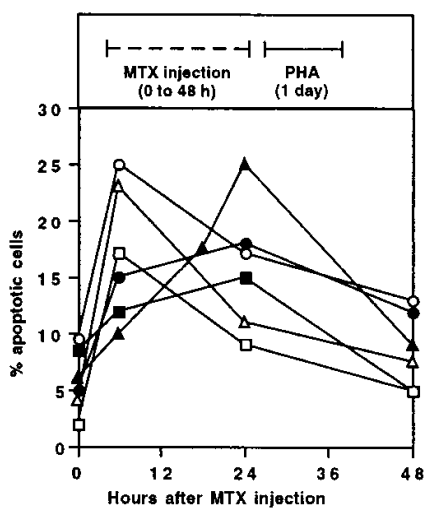

Figure 8. Ex vivo activation of PBL after MTX injection induces apoptosis. Six patients with rheumatoid arthritis under long-term treatment by MTX were studied. Blood samples were taken at indicated times after MTX (7.5-15 $\mathrm{mg} / \mathrm{kg}$ ) intramuscular injection, and PBL were activated by PHA $(5 \mu \mathrm{g} / \mathrm{ml})$. Percentages of apoptotic cells (Hoechst 33342 staining) were determined after $24 \mathrm{~h}$ PHA activation. Each symbol repre-

sents one patient. Cultures in the presence of folic acid $(100 \mu \mathrm{M})$ or folinic acid $(10 \mu \mathrm{M})$ resulted in $1-5 \%$ specific apoptosis, as defined in Methods.

than that observed after in vitro incubation of normal PBL with MTX. Nevertheless, uptake and intracellular retention of MTX, along with the irreversibility of its effect on activated lymphocytes, provide a rationale for intermittent administration in contrast with other antiinflammatory and immunosuppressive agents that must be administered daily because of their short half-life and/or reversible activity.

Polyglutamated MTX not only blocks DHFR, the main target enzyme of MTX, but also inhibits a number of folatedependent enzymes, resulting in inhibition of purine and thymidylate synthesis $(10,11)$. Complete blockade of DHFR results in the depletion of intracellular reduced folates, but the apoptotic activity of MTX was only reversed at high molar ratios of folic acid to MTX, and much more efficiently by folinic acid, which bypasses DHFR. Complete inhibition by exogenous thymidine supports the prediction that this immunosuppressive activity of MTX may be primarily controlled by intracellular levels of thymidine.

Adenosine accounted for only a minor part of MTX-induced apoptosis because adenosine-triggered apoptosis was restricted to a small subset $(\sim 15 \%)$ of activated PBL. As discussed below, programmed cell death of activated PBL after MTX treatment was initiated at the onset of the $S$ phase of the cell cycle. It may be hypothesized that the apoptotic-triggering signal is generated by altered DNA strands produced by DNA polymerase in the absence of thymidine, thus inducing apoptotic pathways shared by various genotoxic agents, and involving $\mathrm{p} 53$, the product of the retinoblastoma susceptibility gene $\mathrm{Rb}$, and multimeric kinase complexes that control the G1/S progression (33-35). However, the apoptotic-signaling pathways induced by altered DNA are still largely unknown. In this respect, it is noteworthy that the antiproliferative properties of MTX demonstrated at high $(100 \mu \mathrm{M})$ and low $(0.01 \mu \mathrm{M})$ concentrations are clearly independent from its apoptosis-inducing capacity, suggesting that G1/S progression and apoptosis may be controlled by distinct signaling pathways.

It has recently been reported that several cytotoxic drugs, including MTX, can trigger CD95 (Fas, APO-1) ligand expression in leukemia $\mathrm{T}$ cell lines (22) and hepatoma cell lines (36), and that CD95 ligand/CD95 interactions were critical in druginduced apoptosis. However, in activated PBL, MTX triggered apoptosis by a CD95-independent pathway. This observation is of major relevance for therapeutic applications because CD95-dependent apoptosis is restricted to a subset of preactivated "memory" $\mathrm{T}$ cells that express the CD45 RO short isoform (37-39), and that have developed sensitivity to the CD95mediated apoptosis pathway through an efficient IL-2 signal (23). Conversely, MTX induces apoptosis of naive as well as memory $\mathrm{T}$ cells, and may induce deletion of naive activated $\mathrm{T}$ cells, as shown by MLR experiments.

MTX is usually used as monotherapy in autoimmune diseases, but in association with other immunosuppressive drugs, such as CsA or FK 506, in graft-versus-host diseases, and organ allograft rejection (4-8). The present study indicates that blocking the IL-2 pathway by inhibition of gene transcription (CsA, FK 506), anti-IL-2 receptor antibodies (CD25) or drugs interfering with IL-2 signaling (rapamycin) that block activated T cells in the G1 phase of the cell cycle, prevents MTXinduced apoptosis in vitro. Therefore, one should not expect synergy between MTX and drugs that interfere with the IL-2 pathway, unless MTX deletes T cells that have escaped activation blockade by the associated drugs. This could be the case in autoimmune disorders where CsA is administrated at much lower doses than in transplantation.

In conclusion, the present study demonstrates that lowdose MTX treatment can induce apoptosis and clonal deletion of activated $\mathrm{T}$ cells, and, thus, establishes the potent immunosuppressive properties of this drug. The model provides a rationale for intermittent administration and it could be applied to optimizing the pharmacokinetics of MTX treatment. However, the relative irreversibility of this effect may represent a risk of overimmunosuppression in long-term therapy.

\section{Acknowledgments}

We acknowledge the help of O. Assossou who performed PCR experiments, M. Mutin who performed electron microscopy studies, M. Flacher who performed MLR experiments, and we thank N. Bonnefoy-Bérard and $\mathrm{T}$. Greenland for critical reading of the manuscript.

This work was supported by grants from the Région Rhône-Alpes (H098730000, J.P. Revillard) and Fondation pour la Recherche Médicale.

\section{References}

1. Farber, S., R. Toch, E. Manning Sears, and D. Pinkel. 1956. Advances in chemotherapy of cancer in man. In Advances in Cancer Research. H.A. Greenstein J.-P., editor. Academic Press, New York. 2-73.

2. Weinblatt, M.E., J.S. Coblyn, D.A. Fox, P.A. Fraser, D.E. Holdsworth, D.N. Glass, and D.E. Trentham. 1985. Efficacy of low-dose methotrexate in rheumatoid arthritis. N. Engl. J. Med. 312:818-822.

3. Williams, H.J., R.F. Wilkens, C.O. Samuelson, G.S. Alarcon, M. Guttadauria, C. Yarboro, R.P. Polisson, S.R. Weiner, M.E. Luggen, L.M. Billingsley, et al. 1985. Comparison of low-dose oral pulse methotrexate and placebo in the treatment of rheumatoid arthritis: a controlled clinical trial. Arthritis Rheum. 28:721-730.

4. Storb, R., H.J. Deeg, J. Whitehead, F. Appelbaum, P. Beatty, W. Bensinger, D. Buckner, R. Clift, K. Doney, V. Farewell, et al. 1986. Methotrexate and cyclosporine compared with cyclosporine alone for prophylaxis of acute graft-versus-host disease after marrow transplantation for leukemia. N. Engl. J. Med. 314:729-735.

5. Nash, R.A., M.S. Pepe, R. Storb, G. Longton, M. Pettinger, C. Anasetti, F.R. Appelbaum, R.A. Bowden, H.J. Deeg, K. Doney, et al. 1992. Acute graftversus-host disease: analysis of risk factors after allogeneic marrow transplantation and prophylaxis with cyclosporine and methotrexate. Blood. 80:1838-1845.

6. Chao, N.J., G.M. Schmidt, J.C. Niland, M.D. Amylon, A.C. Dagis, G.D. Long, A.P. Nademanee, R.S. Negrin, M.R. O'Donnell, P.M. Parker, et al. 1993. Cyclosporine, methotrexate, and prednisone compared with cyclosporine and prednisone for prophylaxis of acute graft-versus-host disease. N. Engl. J. Med. 329:1225-1230.

7. Nash, R.A., L.A. Pineiro, R. Storb, J.H. Deeg, W.E. Fitzsimmons, T. Fur- 
long, J.A. Hansen, T. Gooley, R.M. Maher, P. Martin, et al. 1996. FK506 combination with methotrexate for the prevention of graft-versus-host disease after marrow transplantation from matched unrelated donors. Blood. 88:3634-3641.

8. Olsen, S.L., J.B. O'Connell, M.R. Bristow, and D.G. Renlund. 1990. Methotrexate as an adjunct in the treatment of persistent mild cardiac allograft rejection. Transplantation. 50:773-775.

9. Jolivet, J., R.L. Schilsky, B.D. Bailey, J.C. Drake, and B.A. Chabner. 1982. Synthesis, retention, and biological activity of methotrexate polyglutamates in cultured human breast cancer cells. J. Clin. Invest. 70:351-360.

10. Jolivet, J., and B.A. Chabner. 1983. Intracellular pharmacokinetics of methotrexate polyglutamates in human breast cancer cells. J. Clin. Invest. 72 : 773-778.

11. Chabner, P.A., C.J. Allegra, G.A. Curt, N.J. Clendeninn, J. Baram, S. Koisumi, J.C. Drake, and J. Jolivet. 1985. Polyglutamation of methotrexate. Is methotrexate a prodrug? J. Clin. Invest. 76:907-912.

12. Allegra, C.J., J.C. Drake, J. Jolivet, and B.A. Chabner. 1985. Inhibition of phosphoribosyl-aminoimidazole-carboxamide transformylase by methotrexate and dihydrofolic acid polyglutamates. Proc. Natl. Acad. Sci. USA. 82:48814885.

13. Vincent C., S. Fournel, J. Widjenes, and J.P. Revillard. 1995. Specific hyporesponsiveness of alloreactive peripheral T cells induced by CD4 antibodies. Eur. J. Immunol. 25:816-822.

14. Fournel, S., L. Genestier, J.-P. Rouault, G. Lizard, M. Flacher, O. Assossou, and J.-P. Revillard. 1995. Apoptosis without decrease of cell DNA content. FEBS Lett. 367:188-192.

15. Koopman, G., C. Reutelingsperger, G. Kuijten, R. Keehnen, S. Pals, and M. Van Oers. 1994. Annexin V for flow cytometric detection of phosphatidylserine expression on B cells undergoing apoptosis. Blood. 84:1415-1420.

16. Gorczyca, W., J. Gong, and Z. Darzynkiewicz. 1993. Detection of DNA strand breaks in indvidual apoptotic cells by the in situ terminal deoxynucleotidyl transferase and nick translation assays. Cancer Res. 53:1945-1951.

17. Benhamou, L.E., P.A. Cazenave, and P. Sarthou. 1990. Anti-immunoglobulins induce death by apoptosis in WEHI-231 B lymphoma cells. Eur. J. Immunol. 20:1405-1407.

18. Zamzami, N., P. Marchetti, M. Castedo, C. Zanin, J.-L. Vayssière, P.X. Petit, and G. Kroemer. 1995. Reduction in mitochondrial potential constitutes an early irreversible step of programmed lymphocyte death in vivo. J. Exp. Med. 181:1661-1672

19. Fournel, S., E. Robinet, N. Bonnefoy-Bérard, O. Assossou, M. Flacher, H. Waldmann, G. Bismuth, J.-P. Revillard. 1998. A noncomitogenic CD2R monoclonal antibody induces apoptosis of activated T cells by a CD95/CD95-Ldependent pathway. J. Immunol. 160: 4313-4321.

20. Rieux-Laucat, F. F. Le Deist, C. Hivroz, I. A G. Roberts, K.M. Debatin, A. Fischer, and J.P. de Villartay. 1995. Mutations in Fas associated with human lymphoproliferative syndrome and autoimmunity. Science. 268:1347-1349.

21. Cronstein, B.N., D. Naime, and E. Ostad. 1993. The antiinflammatory mechanism of methotrexate. Increased adenosine release at inflamed sites diminishes leukocyte accumulation in an in vivo model of inflammation. J. Clin. Invest. 92:2675-2682.

22. Friesen, C., I. Herr, P.H. Krammer, and K.-M. Debatin. 1996. Involvement of the CD95 (APO-1/Fas) receptor/ligand system in drug-induced apoptosis in leukemia cells. Nat. Med. 2:574-577.

23. Fournel, S., L. Genestier, E. Robinet, M. Flacher, and J.-P. Revillard. 1996. Human T cells require IL-2 but not G1/S transition to acquire susceptibility to Fas-mediated apoptosis. J. Immunol. 157:4309-4315.

24. Singer, A., and F. Bach. 1995. Allograft immunity: in vitro and in vivo studies. In Transplantation Immunology. F. Bach and H. Auchincloss, editors. Wiley-Liss, New York. 105-111.

25. Cronstein, B.N., E.D. Rosenstein, S.B. Kramer, G. Weissmann, and R. Hirschhorn. 1985. Adenosine: a physiologic modulator of superoxide anion generation by human neutrophils. Adenosine acts via an A2 receptor on human neutrophils. J. Immunol. 135:1366-1371.

26. Cronstein, B.N., R.I. Levin, J. Belanoff, G. Weissmann, and R. Hirschhorn. 1986. Adenosine: an endogenous inhibitor of neutrophil-mediated injury to endothelial cells. J. Clin. Invest. 78:760-770.

27. Cronstein, B.N., M.A. Eberle, H.E. Gruber, and R.I. Levin. 1991. Methotrexate inhibits neutrophil function by stimulating adenosine release from connective tissue cells. Proc. Natl. Acad. Sci. USA. 88:2441-2445.

28. Morabito, L., M.C. Montesinos, D.M. Schreibman, L. Balter, L.F. Thompson, R. Resta, G. Carlin, M.A. Huie, B.N. Cronstein. 1998. Methotrexate and sulfasalazine promote adenosine release by a mechanism that requires ecto-5-nucleotidase-mediated conversion of adenosine nucleotides. J. Clin. Invest. 101:295-300.

29. Cronstein, B.N., and R. Hirschhorn. 1990. Adenosine and host defense. In Adenosine and Adenosine Receptors. M. Williams, editor. The Human Press, Clifton, NJ. 475-500.

30. Sonneveld, P., F. Schultz, K. Nooter, and K. Hahlen. 1986. Pharmacokinetics of methotrexate and 7-hydroxy-methotrexate in plasma and bone marrow of children receiving low-dose oral methotrexate. Cancer Chemother. Pharmacol. 18:111-116.

31. Wallace, C., W. Bleyer, D. Sherry, D. Salmonson, and R. Wedgewood. 1989. Toxicity and serum levels of methotrexate in children with juvenile rheumatoid arthritis. Arthritis Rheum. 32:677-681.

32. Sinnett, M., G. Groff, D. Raddatz, W. Franck, and J. Bertino. 1989. Methotrexate pharmacokinetics in patients with rheumatoid arthritis. J. Rheumatol. 16:745-748.

33. Lowe, S.W., H.E. Ruley, T. Jacks, and D.E. Housman. 1993. p53-dependent apoptosis modulates the cytotoxicity of anticancer agents. Cell. 74:957-967.

34. Fisher, D.E. 1994. Apoptosis in cancer therapy: crossing the threshold. Cell. 78:539-542.

35. Almasan, A., Y. Yin, R.E. Kelly, E. Lee, A. Bradley, W. Li, J. Bertino, and G. Wahl. 1995. Deficiency of retinoblastoma protein leads to inappropriate S-phase entry, activation of E2F-responsive genes, and apoptosis. Proc. Natl. Acad. Sci. USA. 92:5436-5440.

36. Müller, M., S. Strand, H. Hug, E.-M. Heinemann, H. Walczak, W. Hofmann, W. Stremmel, P. Krammer, and P. Galle. 1997. Drug-induced apoptosis in hepatoma cells is mediated by the CD95 (APO-1/Fas) receptor/ligand system and involves activation of wild-type p53. J. Clin. Invest. 99:403-413.

37. Genestier, L., R. Paillot, N. Bonnefoy-Bérard, G. Meffre, M. Flacher, D. Fèvre, Y.J. Liu, P. Le Bouteiller, H. Waldmann, V.H. Engelhard, J Banchereau, and J.-P. Revillard. 1997. Fas-independent apoptosis of activated T cells induced by antibodies to the HLA class I $\alpha 1$ domain. Blood. 90:36293639 .

38. Brugnoni, D., P. Airo, F. Facchetti, L. Blanzuoli, A.G. Ugazio, R. Cattaneo, and L.D. Notarangelo. 1997. In vitro death of activated lymphocytes in Omenn's syndrome. Eur. J. Immunol. 27:2765-2773.

39. De Maria, R., M. Boirivant, M.G. Cifone, P. Roncaioli, M. Hahne, J. Tschopp, F. Pallone, A. Santoni, and R. Testi. 1996. Functional expression of Fas and Fas ligand on human gut lamina propria $\mathrm{T}$ lymphocytes. A potential role for the acidic sphingomyelinase pathway in normal immunoregulation. $J$. Clin. Invest 97:316-322. 